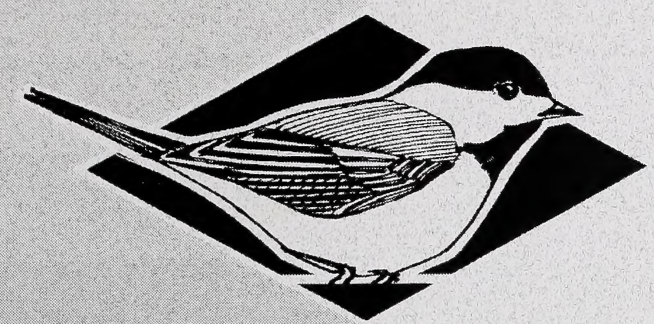

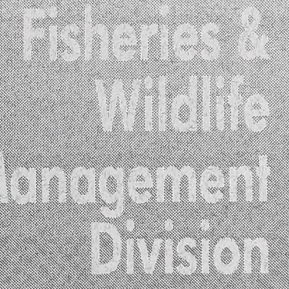

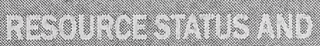

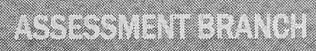

\section{Survey of the Peregrine Falcon \\ (Falco peregrinus anatum) in Alberta}

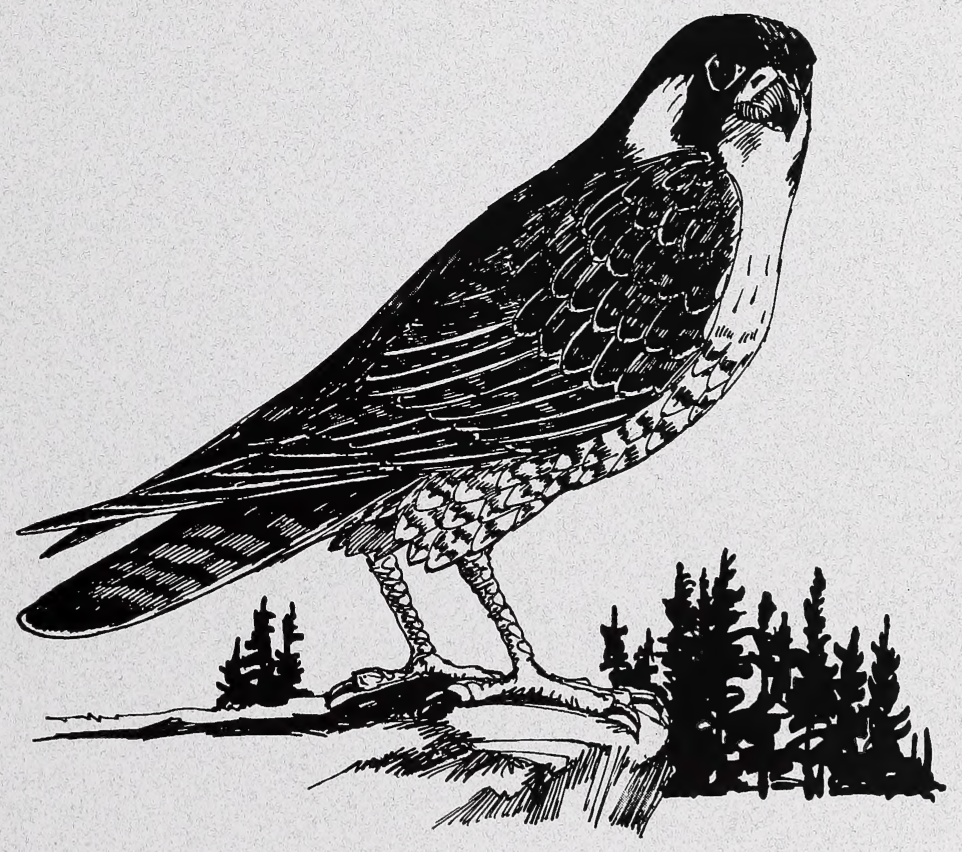

Alberta Species at Risk Report No. 2 
Digitized by the Internet Archive in 2016

https://archive.org/details/surveyofperegrin00corr_0 


\title{
Survey of the Peregrine Falcon (Falco peregrinus anatum) in Alberta
}

\author{
Rob Corrigan
}

Alberta Species at Risk Report No. 2

March 2001

Project Partners:
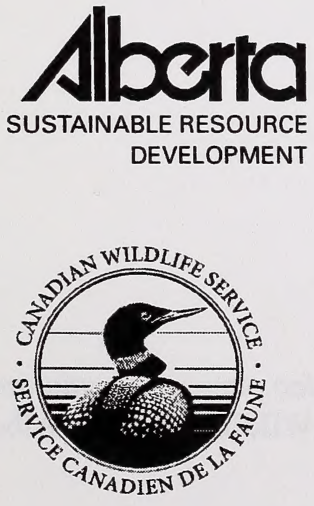

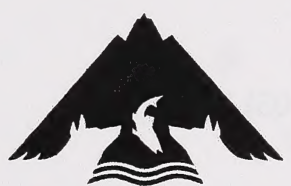

Alberta Conservation Association
Parks Parcs

Canada Canada 
Publication No.: I/002

ISBN: 0-7785-1748-9 (Printed Edition)

ISBN: 0-7785-1749-7 (On-line Edition)

ISSN: 1496-7219 (Printed Edition)

ISSN: 1496-7146 (On-line Edition)

Illustration: Brian Huffman

For copies of this report, contact:

Information Centre - Publications

Alberta Environment / Alberta Sustainable Resource Development

Main Floor, Great West Life Building

9920108 Street

Edmonton, Alberta

Canada

T5K 2M4

Telephone: (780) 422-2079

\section{OR}

Information Service

Alberta Environment / Alberta Sustainable Resource Development \#100, 311512 Street NE

Calgary, Alberta

Canada

T2E 7J2

Telephone: (403) 297-3362

This publication may be cited as:

Corrigan, R. 2000. Survey of the peregrine falcon (Falco peregrinus anatum) in Alberta. Alberta Sustainable Resource Development, Fish and Wildlife Service, Alberta Species at Risk Report No. 2. Edmonton, AB. 17 pp. 


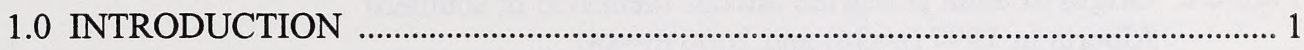

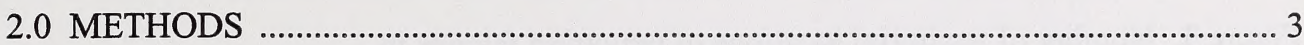

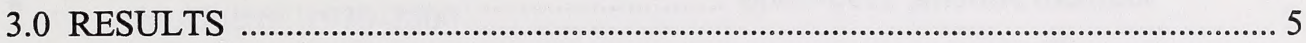

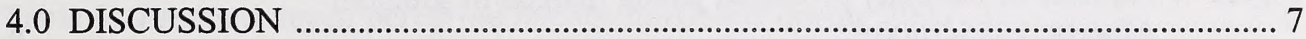

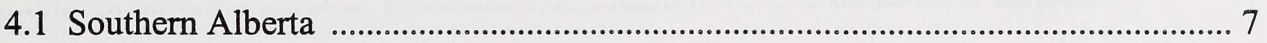

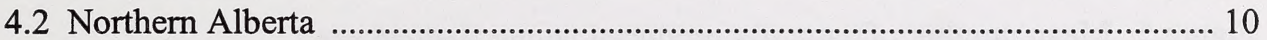

5.0 MANAGEMENT IMPLICATIONS AND FUTURE DIRECTIONS ...................... 11

5.1 Assessment of Project Goals ............................................................................... 11

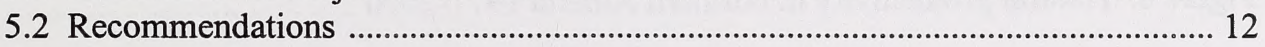

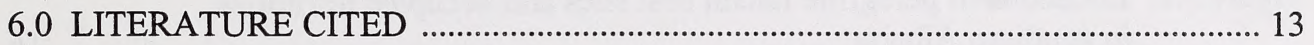

Appendix A. Locations of Nesting and Territorial Peregrine Falcons in Alberta ........... 15 


\section{LIST OF FIGURES}

Figure 1. Total number of occupied peregrine falcon territories in Alberta, 1970-2000

Figure 2. Origin of adult peregrine falcons identified in southern Alberta in $1997(n=34)$ and $2000(n=45)$

Figure 3. Number of territorial locations of peregrine falcons in southern Alberta, 1995-2000 8

Figure 4. Number of naturally produced young fledged in southern Alberta, 1995-2000

Figure 5. Mean number of naturally produced young fledged per territorial pair per year in southern Alberta, 1995-2000

Figure 6. Natural productivity in northern Alberta 1971-2000 11

Figure A1. Locations of peregrine falcon nest sites and occupied territories in southern Alberta 16

Figure A2. Locations of nest sites and occupied territories in northeast Alberta, 2000 


\section{LIST OF TABLES}

Table 1. Survey terminology

Table 2. Rivers in southern Alberta that were surveyed during the 2000 Provincial Peregrine Falcon Survey

Table 3. Number of occupied territories in Alberta during 2000 5

Table 4. Total number of occupied territories for peregrine falcons in Alberta, 1970-2000 5

Table 5. Productivity of peregrine falcons in Alberta during 2000 6 


\section{ACKNOWLEDGEMENTS}

The completion of the 2000 Alberta Peregrine Falcon Survey was made possible through the contribution of many individuals. The following people were instrumental in survey design and implementation: from Alberta Fisheries and Wildlife Management Division, Gary Erickson (Lethbridge), Pat Young (Calgary), Ken Froggatt (Red Deer), Dave Moore (Vermilion), Dr. Wayne Nelson (St. Paul), Dr. Gordon Court (Edmonton); Dr. Geoff Holroyd (Canadian Wildlife Service); and Mark Bradley, Christie Wickenheiser and Bob Reside (Parks Canada, Wood Buffalo National Park) assisted with surveys in northeast Alberta.

The following people contributed as observers during surveys: from Alberta Fisheries and Wildlife Management Division, Rose Jones, Laurel Barney, Sue Cotterill, Kim Morton, Mikael Christensen; from the Alberta Conservation Association, Dave Fairless, Joanne Melzer, Daryl Kublik, Dave Park and Bill Patterson; from Wood Buffalo National Park, David Campbell, Libby Gunn, Willie Courtoreille, Kevin Busch, Brian Johns, Doug Williamson, Dan Potvin, Dallas Campbell and Adam Moreland.

I would like to thank Hank Killian, Alberta Fisheries and Wildlife Management Division, for his time and energy surveying and monitoring peregrine falcon production on the Red Deer River and in central Alberta.

The Alberta Natural Heritage Information Centre (ANHIC) provided the maps contained in this report. Lance Engley of the Alberta Conservation Association loaded the data into the Biodiversity/Species Observation Database (BSOD).

Funding for the 2000 Provincial Peregrine Survey came from Alberta Fisheries and Wildlife Management Division, Alberta Conservation Association, Canadian Wildlife Service, Environment Canada and Parks Canada.

I would like to thank the following people for providing editorial comments: Jody Willis, Dr. David Prescott, Dr. Gordon Court and Nyree Sharp (all from Alberta Fisheries and Wildlife Management Division) and Dr. Geoff Holroyd (Canadian Wildlife Service). I would especially like to thank Dr. Gordon Court for his assistance during the project. His thoughtful insight, knowledge and support throughout this project are greatly appreciated.

This project was completed when the Fisheries and Wildlife Management Division was part of Alberta Environment; this division is now part of Alberta Sustainable Resource Development. 


\section{EXECUTIVE SUMMARY}

There are three sub-species of peregrine falcons (Falco peregrinus) found in Canada; only the anatum sub-species breeds in Alberta. Prior to the 1970s, peregrine falcons could be found throughout Alberta. They nested on cliffs along the major river systems of southern Alberta and, in northern Alberta, nested along the north shore of Lake Athabasca, the riverbanks of northeastern Alberta and on rock outcrops throughout the Canadian Shield. This species was extirpated in southern Alberta in the early 1970s, mainly because of reproductive failure caused by organochlorine pesticides.

Organochlorine pesticides bioaccumulate in peregrine tissue, affecting breeding success by causing the production of thin eggshells. In the early 1970s, the Canadian Wildlife Service (CWS) initiated a captive-breeding program that would eventually provide captive-raised peregrines to release into the wild. The first national Peregrine Falcon Survey was completed in 1970, and since then national surveys have been completed every five years. Alberta has committed to surveying peregrines on a provincial basis as a component of the five-year national surveys. In 2000, Alberta was surveyed comprehensively as part of the 2000 national survey.

Provincially, 48 territorial pairs of peregrines were located in the 2000 survey: 23 in the southern Alberta population (south of $58^{\circ}$ ), and 25 pairs in the northern population (north of $58^{\circ}$ ). Survey effort was focused on previously known nesting locations and on suitable habitat in proximity to known historical nest sites. Surveying was completed by helicopter, jet boat and by foot. All nest locations were monitored for productivity and the young were banded when possible. Locations, nest site productivity and band readings were recorded and entered into the Biodiversity/Species Observation Database (BSOD) of Alberta Fisheries and Wildlife and the Alberta Conservation Association. Incidental observations of bald eagles (Haliaeetus leucocephalus), golden eagles (Aquila chrysaetos), ferruginous hawks (Buteo regalis) and prairie falcons (Falco mexicanus) were recorded similarly. 


\subsection{INTRODUCTION}

In Canada, there are three sub-species of peregrine falcon (Falco peregrinus), of which the anatum sub-species is the only one to breed in Alberta. Historically, the peregrine falcon nested throughout southern Alberta (south of $58^{\circ}$ ) along major rivers systems, and in northern Alberta (north of $58^{\circ}$ ) on Canadian Shield outcroppings and cliffs along lakes and rivers. The actual number of pairs of peregrine falcon that nested in Alberta before population declines occurred is unknown.

Nest failures resulted from the widespread use of organochlorine pesticides, most notably dichlorodiphenyltrichloroethane (DDT), which caused a decline of peregrine populations worldwide (Peakall et al. 1990, Court 1993b). DDE (dichlorodiphenyldichloroethylene, the primary metabolite of DDT) inhibits the release of calcium during the egg laying process, resulting in thin eggshells. During incubation, the weight of the incubating parent results in reproductive failure through eggshell breakage. Such reproductive failure was linked to a drastic decline in peregrine falcon numbers throughout North America during the 1950s and 1960s. The first North American peregrine survey was conducted in 1970; subsequent surveys were conducted at five-year intervals (Cade and Fyfe 1970). Results from the 1970 survey confirmed that the declining trend in peregrine populations was continuing, and the peregrine falcon was subsequently listed as an endangered species by both COSEWIC, in 1978 (COSEWIC 2000), and the United States, in 1970 (Millsap et al. 1998).

In an effort to preserve the anatum gene pool, the Canadian Wildlife Service removed nestling peregrines from remnant wild pairs for the purpose of developing a captivebreeding program. The breeding stock would eventually supply captive-raised chicks for release into the wild once the environment was conducive to peregrine falcon reproductive success. DDT was banned for use in Canada in 1969 and in the United States in 1972 (Court 1993b), however the decline of nesting peregrines in Canada continued through the 1970s. The last known successful breeding pair of peregrines in southern Alberta was observed in 1972 and the last known territorial adult was extirpated by 1975 (Fyfe et al. 1976). By the mid 1970s the anatum peregrine was extirpated in southern Alberta and by 1975 there were only three known breeding pairs of peregrines in northern Alberta (Fyfe et al. 1976).

By 1975 , success in captive breeding made possible the introduction of captive-raised chicks into the wild through fostering and hack releases (Fyfe et al. 1976). Both captiveraised and wild-born peregrines continued to show accumulations of pesticide residue in the eggs and eggshells that were collected in the wild. Fostering and hack release of peregrines continued through the 1970s and 1980s and met modest success. Between 1976 and 1985, 131 captive-raised young were released into southern Alberta and, by 1986, 2 pairs of adult peregrines that originated from these releases had fledged young successfully (Murphy 1990).

An analysis of pesticide residues in peregrine eggshells between 1968 and 1992 was completed in 1993 (Court 1993b). The results from this analysis clearly showed that the 
level of pesticide contamination had decreased such that eggshell thickness should not be a limiting factor in peregrine reproductive success. In 1991, 36 prey species were collected and pesticide levels were measured. The results showed a decrease in pesticide levels compared with the 1970s and 1980s (Court 1993b). Environmental conditions were then deemed safe for the release of a large number of captive-raised peregrines.

In 1992, the Southern Alberta Peregrine Falcon Reintroduction Project began with the goal of releasing approximately 40 captive-raised peregrine young annually into southern Alberta over a 5-year period (Stepnisky 1996). The objective of the reintroduction project was to meet the goals of the national Anatum Peregrine Falcon Recovery Plan (Erickson et al. 1988), which targeted a minimum of 10 territorial peregrine pairs producing 15 fledged falcons by 1987 (Stepnisky 1996). The 1995 national peregrine survey results showed that the national recovery plan goals had been met in Alberta.

The year 2000 Alberta provincial survey objective was to survey all known historical nesting locations and suitable potential habitat at the prescribed five-year interval. The provincial survey is a component of the national survey done to assess the status of the peregrine falcon and the need for ongoing management. There are a number of known sites north of $60^{\circ}$ in the Northwest Territories that were often counted as part of the northern Alberta population, but were not included in the year 2000 Alberta provincial peregrine falcon survey and survey report. 


\subsection{METHODS}

Terminology used for the survey was taken from Murphy (1990) and is outlined in Table 1. This terminology has been used consistently in provincial and national peregrine surveys since 1985 .

Table 1. Survey terminology (Murphy, 1990).

\begin{tabular}{|l|l|}
\hline Term & Definition \\
\hline Occupied Nest or Territory & $\begin{array}{l}\text { A nest site or territory that is occupied by at least } \\
\text { one territorial adult during some part of the breeding } \\
\text { season. }\end{array}$ \\
\hline Breeding Pair & $\begin{array}{l}\text { A pair that laid at least one egg during breeding } \\
\text { season. }\end{array}$ \\
\hline Productive Pair & $\begin{array}{l}\text { A pair that successfully raised at least one chick to } \\
\text { an advanced stage of development from which the } \\
\text { chick was assumed to have fledged. Chicks that } \\
\text { reached an age suitable for banding are considered to } \\
\text { be of advanced age. }\end{array}$ \\
\hline Historical Nest Site & $\begin{array}{l}\text { Site that has been documented to have been } \\
\text { occupied by breeding adults prior to the decline of } \\
\text { the peregrine falcon population in southern Alberta, } \\
\text { as identified by Court (1993a). }\end{array}$ \\
\hline Known Nest Site & $\begin{array}{l}\text { Site that has been documented to have been } \\
\text { occupied by breeding adults in any year prior to this } \\
\text { survey (includes historic sites plus new sites that } \\
\text { have been occupied since the 1970s) }\end{array}$ \\
\hline
\end{tabular}

In recovering peregrine populations throughout the world, historical nest sites that were used prior to population declines were among the first to be re-established once populations began to recover (Cade and Fyfe 1970, Court 1993a). Survey efforts in Alberta have focused on historical and known nest sites and suitable habitat associated with historical locations. Johnstone (1999) refers to Newton (1988) and Ratcliffe (1993) in describing a suitable breeding site for peregrines as: 1) "a well drained stable area which is large enough for at least 3 large nestlings to lie down in, and which is preferably, but not necessarily, $10 \mathrm{~m}$ or more off the ground", and 2) "[has] access to abundant prey."

In southern Alberta, Court (1993a) identified 60 historical nest sites and there are 48 known sites in northern Alberta (Moore 1995b). In an effort to survey suitable habitat associated with known nest sites, river sections with known sites in southern Alberta were surveyed (Table 2). A total of 58 of 60 known sites were surveyed in southern Alberta while all known nest sites but three were surveyed in northern Alberta. 
Table 2. Rivers in southern Alberta that were surveyed during the 2000 Provincial Peregrine Falcon Survey.

\begin{tabular}{|c|c|c|c|}
\hline River & Start & Finish & Comments \\
\hline Milk & $49^{\circ}$ North & Highway 880 & $\begin{array}{l}\text { Started survey where Milk River } \\
\text { enters Canada, flown by helicopter. }\end{array}$ \\
\hline Oldman & Fort McLeod & Grand Forks & $\begin{array}{l}\text { MacGregor Reservoir also } \\
\text { surveyed, flown by helicopter. }\end{array}$ \\
\hline St. Mary's & St. Mary's Reservoir & $\begin{array}{l}\text { Confluence with } \\
\text { Oldman }\end{array}$ & Flown by helicopter. \\
\hline Bow & Ghost Reservoir & Grand Forks & $\begin{array}{l}\text { City of Calgary and Siksika Nation } \\
\text { not done, flown by helicopter. }\end{array}$ \\
\hline Highwood & Highway 40 & Sheep confluence & $\begin{array}{l}\text { Portion after confluence to Bow } \\
\text { River also completed, flown by } \\
\text { helicopter. }\end{array}$ \\
\hline Sheep & Windy Point & Highwood confluence & As above. \\
\hline Red Deer & City of Red Deer & $\begin{array}{l}\text { Confluence with } \\
\text { Rosebud River }\end{array}$ & $\begin{array}{l}\text { Also complete were Ghostpine, } \\
\text { Threehills and Kneehills Creeks } \\
\text { where suitable habitat existed, } \\
\text { flown by helicopter. }\end{array}$ \\
\hline Rosebud & Rosebud & $\begin{array}{l}\text { Confluence with Red } \\
\text { Deer }\end{array}$ & $\begin{array}{l}\text { Horseshoe Canyon also surveyed, } \\
\text { flown by helicopter. }\end{array}$ \\
\hline North Saskatchewan & Rocky Mtn. House & Fort Saskatchewan & $\begin{array}{l}\text { Flown by helicopter and done by } \\
\text { jet boat. }\end{array}$ \\
\hline Brazeau & Brazeau Reservoir & $\begin{array}{l}\text { Junction with North } \\
\text { Sask. River }\end{array}$ & Flown by helicopter. \\
\hline Pembina & Sangudo & Highway 621 & Flown by helicopter. \\
\hline Athabasca & Brule Rapids & Fort McMurray & Flown by helicopter. \\
\hline Clearwater & Whitemud Falls & Fort McMurray & Flown by helicopter. \\
\hline Peace(a) & Cherry Point & South of Worsley & $\begin{array}{l}\text { Done by jet boat launched at Silver } \\
\text { Valley }\end{array}$ \\
\hline Peace (b) & $\begin{array}{l}\text { N } 6454243 \\
\text { E } 0517130 \text { Zone } 11\end{array}$ & $\begin{array}{l}\text { Wood Buffalo Park } \\
\text { West Boundary }\end{array}$ & Flown by helicopter. \\
\hline
\end{tabular}

Surveys in southern Alberta were completed between May 8 and July 20, 2000. The majority of the surveys were completed between May 8 and June 8. Surveys were completed in northern Alberta between May 18 and May 31, 2000. Subsequent nest visits were completed throughout the province to determine productivity and to band young nestlings. Surveys were conducted during times when a high degree of occupancy by either one or both adult peregrines could be expected. 


\subsection{RESULTS}

The 2000 survey located a total of 48 occupied territories (Table 3). Twenty-three occupied territories were located in southern Alberta and twenty-five occupied territories were located in northern Alberta. Single birds occupied none of the territories during the 2000 breeding season.

Table 3. Number of occupied territories in Alberta during 2000.

\begin{tabular}{|c|c|c|}
\hline & Total Sites & Occupied By: \\
\hline Area & Single Birds & Pairs \\
\hline Alberta South & 0 & 23 \\
\hline Alberta North & 0 & 25 \\
\hline & & 48 \\
\hline Total & $\mathbf{0}$ & $\mathbf{4 8}$ \\
\hline
\end{tabular}

The total number of occupied territories in Alberta located during provincial surveys (from 1970 to 2000) has risen from 3 to 48 (Table 4). In southern Alberta, the number of occupied territories has risen from 1 to 23 . During both the 1975 and 1980 surveys, no occupied territories were found in southern Alberta. In northern Alberta, the number of occupied territories has risen from 2 in 1970 to 25 in 2000.

Table 4. Total number of occupied territories for peregrine falcons in Alberta, 19702000.

\begin{tabular}{|c|c|c|c|c|c|c|c|}
\hline Area & 1970 & 1975 & 1980 & 1985 & 1990 & 1995 & 2000 \\
\hline Alberta South & 1 & 0 & 0 & 2 & 3 & 13 & 23 \\
\hline Alberta North & 2 & 3 & 9 & 6 & 8 & 18 & 25 \\
\hline Total & 3 & 3 & 9 & 8 & 11 & 31 & 48 \\
\hline
\end{tabular}

Locations for the occupied territories in Alberta are shown in Figures A1 and A2. Figure 1 illustrates the increase in the total number of peregrine falcon territories, and the number of territories from the southern and northern populations, between 1970 and 2000 . 


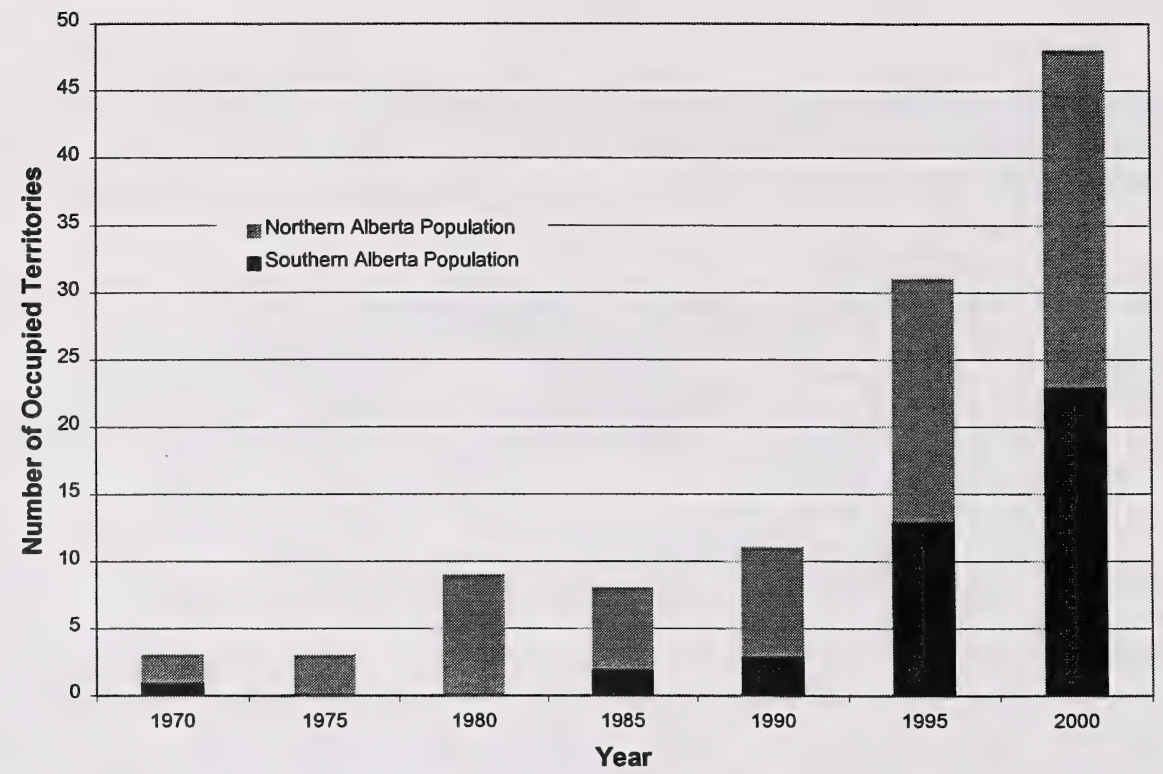

Figure 1. Total number of occupied peregrine falcon territories in Alberta, 1970-2000.

A total of 69 young were produced from a total of 39 breeding pairs (Table 5). The southern Alberta population produced 54 young from a total of 20 breeding pairs and the northern Alberta population produced 15 young from a total of 19 breeding pairs. The number of young per breeding pair was 2.7 in southern Alberta and 0.79 in northern Alberta. Provincially there were 1.44 young per territorial pair and 1.77 young per breeding pair.

Table 5. Productivity of peregrine falcons in Alberta during 2000.

\begin{tabular}{|c|c|c|c|c|c|c|}
\hline Area & $\begin{array}{c}\text { Occupied } \\
\text { Territory }\end{array}$ & $\begin{array}{c}\text { Breeding } \\
\text { Pairs }\end{array}$ & $\begin{array}{c}\text { Productive } \\
\text { Pairs }\end{array}$ & Total Young & $\begin{array}{c}\text { Young/ } \\
\text { Territorial } \\
\text { Pair }\end{array}$ & $\begin{array}{c}\text { Young/ } \\
\text { Breeding } \\
\text { Pair }\end{array}$ \\
\hline Alberta South & 23 & 20 & 18 & 54 & 2.35 & 2.7 \\
\hline Alberta North & 25 & 19 & 5 & 15 & 0.6 & 0.79 \\
\hline & & & & & & \\
\hline Total & $\mathbf{4 8}$ & $\mathbf{3 9}$ & $\mathbf{2 3}$ & $\mathbf{6 9}$ & $\mathbf{1 . 4 4}$ & $\mathbf{1 . 7 7}$ \\
\hline
\end{tabular}

When possible, bands were read on returning peregrines to determine their origin. In 2000, 45 peregrine bands were read on falcons in southern Alberta. The results from band readings in 2000 and the band readings from 1997 are shown in Figure 2. 

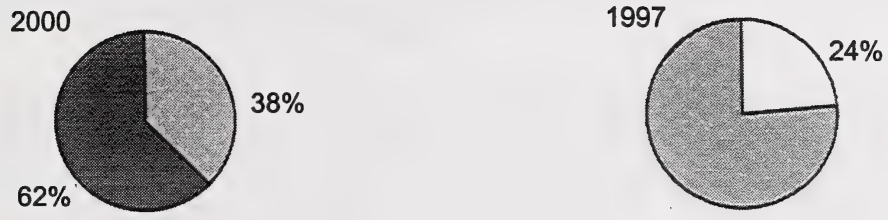

$76 \%$

Figure 2. Origin of adult peregrine falcons identified in southern Alberta in $1997(n=34)$ and $2000(n=45)$. "Captive Raised" includes young that were hack released and those fostered into wild nests.

All territorial and nesting records are stored in the Biodiversity/Species Observation Database (BSOD), and the records specific to the 2000 survey are contained in BSOD under the 2000 Peregrine Falcon Survey report title. In addition to the peregrine falcon locations, nest site activities and observations of pairs or single adults of prairie falcons, (Falco mexicanus; $\mathrm{n}=98$ ), golden eagles (Aquila chrysaetos; $\mathrm{n}=12$ ), bald eagles (Haliaeetus leucocephalus; $\mathrm{n}=1$ ), and ferruginous hawks (Buteo regalis; $\mathrm{n}=33$ ), were recorded. Locations and breeding status information recorded during this survey for these species is also located in BSOD, under the 2000 Peregrine Falcon Survey.

\subsection{DISCUSSION}

\subsection{Southern Alberta}

The results from the 2000 survey show a continued increase in the number of territorial pairs of peregrines found throughout Alberta. The increase from 1995 to 2000 in southern Alberta was from 13 to 23 pairs. In northern Alberta the increase was from 23 to 25 pairs. The search effort for the 2000 survey was similar to previous search efforts, so the increase in the number of territorial pairs can be considered an actual increase.

The southern peregrine population increased dramatically between 1995 and 2000 , however the annual increase has slowed in recent years (Figure 3). This trend is similar to what occurred in northern Alberta with a recovering population. Future monitoring of both southern and northern populations will determine if the number of territorial peregrine falcons is reaching carrying capacity. As mentioned previously, the total number of nesting peregrines prior to the population decline is not known. Therefore, it can not be determined whether current populations are approaching carrying capacity. 


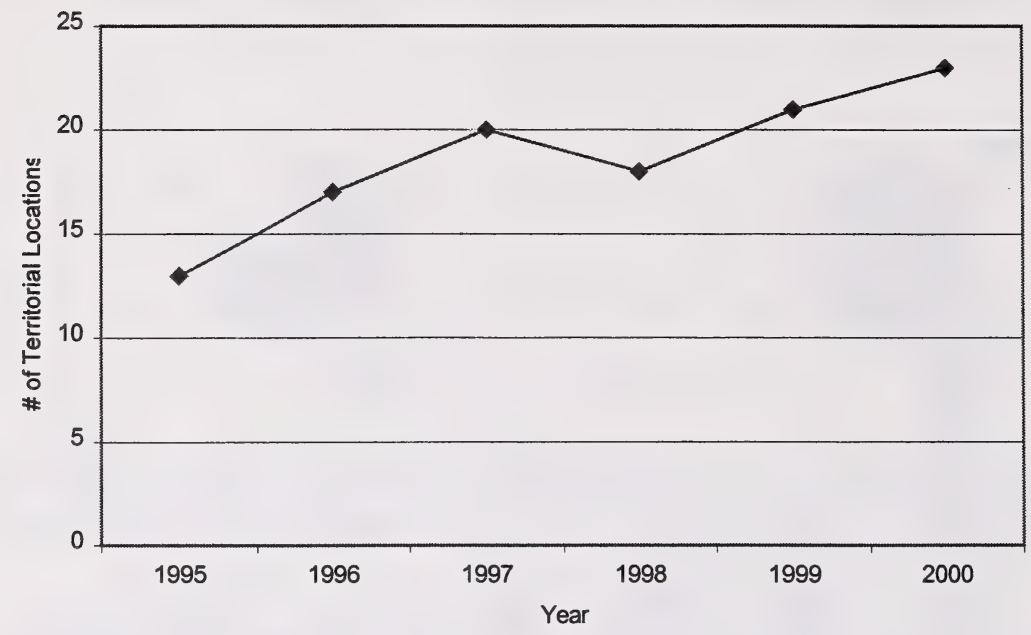

Figure 3. Number of territorial locations of peregrine falcons in southern Alberta, 19952000. (Stepnisky 1998 and Alberta Fisheries and Wildlife, unpublished data.)

In southern Alberta, 9 of the 23 territorial locations were located on rural cliff sites along rivers or lakes. Fourteen sites were located in urban environments or on man-made structures. The low number of territorial locations in natural rural settings is well below the documented number of historical nest sites and most of these historical sites provide suitable nesting locations. Although the peregrine population has been increasing slowly, it is likely that territorial pairs will be located along the major river systems of southern Alberta in the future.

Holroyd and Banasch (1990) found that between 1976 and 1987, 91\% of released peregrines across Canada returned to similar environments (urban vs. rural) from which they were released. Stepnisky (1998) found that this was consistent with urban peregrines $(94 \%)$ but less so with rural peregrines $(61 \%)$ in southern Alberta. It is suggested that peregrines will return to 'first class' sites that are most attractive because of advantageous characteristics of a particular site. Once the 'first class' cliffs are occupied, other less desirable sites will be filled until the population carrying capacity is reached. Throughout North America, peregrine falcons have returned to and established nesting territories in urban environments. The large buildings offer characteristics that make them 'first class' sites. As the number of rural sites increases, and the number of fledged young from rural sites also increases, peregrines should continue to occupy new rural sites until the carrying capacity is reached.

The increase of the peregrine population in Alberta can be attributed to the extensive management (hacking and fostering) of this species since the early 1970s. In 2000, the natural productivity surpassed the greatest number of captive-raised peregrines released in a given year. In 1993, 50 captive-raised peregrines were released into southern 
Alberta. In 2000, 54 naturally produced peregrine young reached an advanced age and were assumed to have fledged (Figure 4). The number of captive-raised young being reintroduced was sufficient to facilitate a population increase. With natural productivity now producing young in similar numbers to released birds, the population increase should continue based on natural productivity.

As the peregrine population re-established, natural productivity remained low. Captiveraised peregrines that entered the breeding population often failed in their early nesting attempts. As the population aged and became more experienced, better quality nest sites were chosen; this resulted in increased productivity (Figure 5). With more experienced peregrines in the breeding population and an increasing number of territories being occupied, the number of naturally produced peregrines fledging also increased.

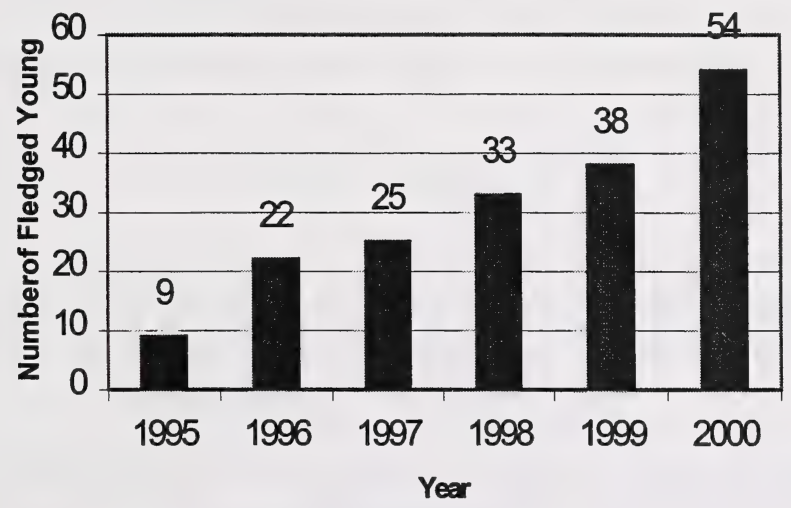

Figure 4. Number of naturally produced young fledged in southern Alberta, 1995-2000 (Alberta Fisheries and Wildlife unpublished data, Stepnisky 1997).

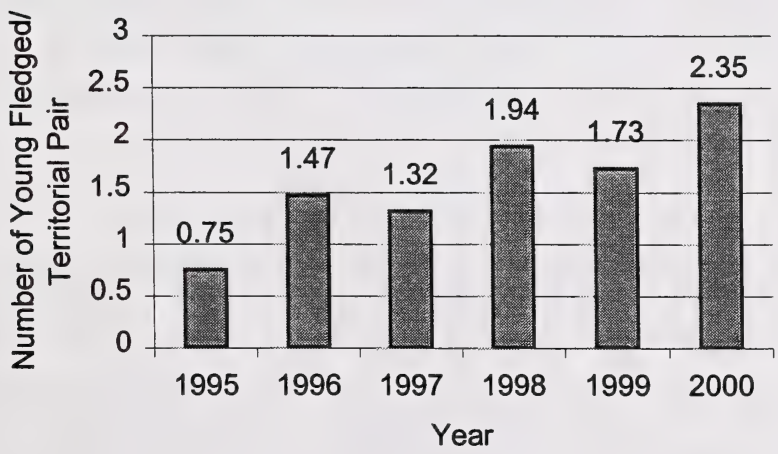

Figure 5. Mean number of naturally produced young fledged per territorial pair per year in southern Alberta, 1995-2000 (Alberta Fisheries and Wildlife unpublished data, Stepnisky 1997). 
An ongoing component of peregrine management in southern Alberta and of the 2000 Alberta survey is banding eyases and monitoring fledging success. Of the 54 young that reached fledging age in southern Alberta, 41 young were banded with a color identification band and a United States Fish and Wildlife aluminum band. The young at four sites were not banded (Wabamun, Sundance, Ardley and Tolman).

Three significant band returns occurred during the summer of 2000. A one-year-old female was found dead at a gas well site at Horseshoe Canyon (near Drumheller); it was banded as an eyas in 1999 at an eyrie on Lummi Island, off Bellingham, Washington, U.S.A. The female that successfully raised young at the Sundance site was banded as an eyas at Peace Point, Wood Buffalo National Park, in 1998. This is the first record of a northern Alberta peregrine breeding in southern Alberta. A 1999 foster chick from the Brazeau Reservoir was found dead on the Horton River, approximately one hundred miles south of the Arctic Ocean. All three of these band returns further indicate that the southern Alberta peregrine population is not a closed population. They also demonstrate the importance of banding peregrine young in Alberta when possible.

\subsection{Northern Alberta}

Survey effort in northern Alberta was similar to inventories conducted in the last major national peregrine five-year survey. All 48 known sites were checked during the 2000 survey. Twenty-three of the known sites were occupied and two new sites were found occupied by peregrines. An increase of seven territorial pairs had occurred in northern Alberta since the 1995 survey. Because of the difficulty and cost associated with accessing many northern sites, a comprehensive survey or monitoring program has not been completed annually at a few of the known sites.

Compared to the southern population, productivity of the northern Alberta population was very poor during 2000 . The northern population produced only 0.6 young per territorial pair, whereas the southern population produced 2.35 young per territorial pair. Nineteen of twenty-three pairs laid, but only five pairs were successful in raising young (fifteen) to fledging age. Addled eggs were collected from two nests, but pesticide analysis has not been completed. At one site (Flett Lake), nest site failure was likely caused by the predation of young by red fox (Vulpes vulpes).

Using the five-year survey to assess productivity may not be accurate, as wide fluctuations in annual productivity occur. Court (1994) found that productivity (the number of young to reach banding age per number of territorial pairs) between 1971 and 1993 in northern Alberta averaged 1.35 \pm 0.82 . In three years -1975, 1982 and $1986-$ the northern Alberta population experienced no natural productivity, which illustrates the risk of using the five-year survey in determining productivity. Figure 6 illustrates the natural variation in productivity that has occurred in northern Alberta. Although the productivity in northern Alberta was low in 2000, this cannot be taken as indicative of a population trend. Stepnisky (1998) also noted the high variability of productivity in the recovering southern Alberta population between 1979 and 1997. Both Court (1994) and 
Stepnisky (1998) demonstrate the natural variations in productivity and the importance of long-term productivity data in modeling recovering peregrine populations.

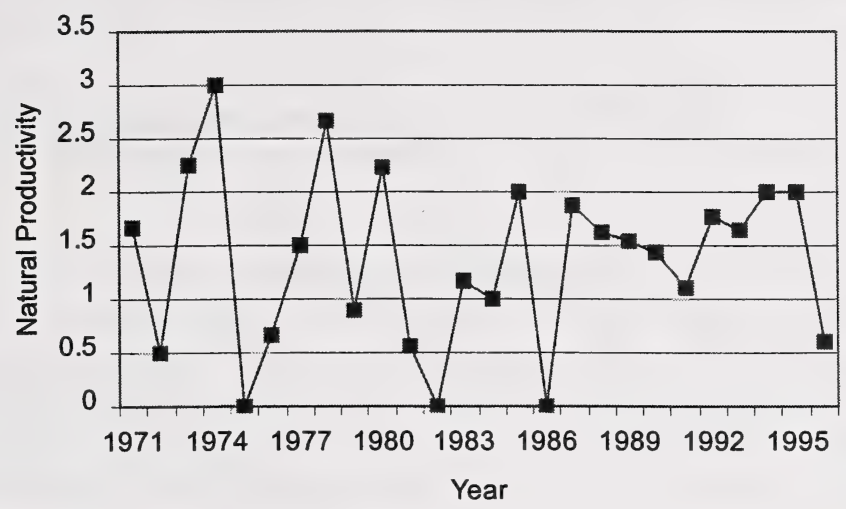

Figure 6. Natural productivity in northern Alberta 1971-2000 (Court 1994, Moore 1995a and 1995b).

\subsection{MANAGEMENT IMPLICATIONS AND FUTURE DIRECTIONS}

\subsection{Assessment of Project Goals}

Project goals for the 2000 Alberta Peregrine Falcon Survey were to survey known historical peregrine falcon nesting locations. In southern Alberta, 58 out of 60 historical and known sites as identified by Court (1993a) and Fish and Wildlife (unpublished data) were surveyed. The two sites that were not surveyed are no longer suitable for nesting by peregrines. In addition to the historical nesting sites that were surveyed, any locations that have had recent peregrine nesting activity or sightings were also surveyed. The search effort in 2000 was similar to past five-year surveys, which focussed on known nesting locations. In addition to surveying known and historical sites, suitable habitat in proximity to the sites was also surveyed. An initial survey occurred in May and June, and if peregrines were present then additional site visits were made during the breeding season to determine productivity, identify adults and band young.

The search effort in northern Alberta was consistent with past five-year surveys. All known and historical nest sites (48) were surveyed. In addition to historical sites, suitable habitat was also surveyed, which resulted in two additional nest sites being located. An initial presence/absence survey was conducted in May and additional site visits were conducted during the breeding season to determine productivity.

The objective of the 1988 Anatum Peregrine Falcon Recovery Plan (Erickson et al. 1988) was to have ten territorial pairs producing an average of fifteen fledged young in all of the six zones representing the anatum range. Southern Alberta is located in the Prairie Zone (Zone 3) and northern Alberta is in the Mackenzie Valley Zone (Zone 4). Alberta's 
contribution to these zones alone has exceeded the objectives of the 1988 Anatum Recovery Plan. In 1999, the national status of anatum peregrine falcons was changed to Threatened (COSEWIC 2000). Within Alberta, the management goal for the peregrine falcon was to increase the population size to a number where it was no longer endangered. In 2000, the official designation of the peregrine falcon under the Alberta Wildlife Act was down-listed from Endangered to Threatened (Endangered Species Conservation Committee 2000). A review of the status of the peregrine in Alberta will be completed in 2001.

\subsection{Recommendations}

Considering the current official designation of the peregrine falcon in Alberta, management of the peregrine falcon in the province over the next few years should focus on continued monitoring of known nesting locations, and any future survey efforts should focus on areas with a high probability of new nesting sites being located. In southern Alberta, all the known nesting locations are well documented and easily accessible. Ongoing spring surveys for presence/absence during the early breeding season and continued monitoring throughout the breeding season should continue. When possible, banding young and reading bands on adults should remain a high priority to further understand the population demographics of this recovering population.

Future annual surveys should remain focused on areas with high quality habitat, areas with active peregrine nesting sites nearby and historical sites. The North Saskatchewan River, between Rocky Mountain House and Berrymore Ferry, and the Red Deer River, between the City of Red Deer and Morin, should be considered the highest priority areas for annual surveys. Both of these river sections can be surveyed effectively by jet boat. The peregrine falcon has made a dramatic comeback to its natural environment in southern Alberta. The recovery, however, is not complete and ongoing management should continue with annual surveys, productivity monitoring and banding of young.

In northern Alberta, the feasibility of ongoing peregrine management is limited by accessibility issues and associated costs. Many of the active peregrine sites in northern Alberta, however, can be accessed easily by boat out of Fort Chipewyan. These sites could become a standardized block of nest sites to be monitored annually through a cooperative agreement with Parks Canada, Canadian Wildlife Service and Alberta Fisheries and Wildlife staff. A dramatic shift in the population size and productivity could be detected through a standard survey that is done annually without the associated costs of widespread monitoring in northern Alberta. 


\subsection{LITERATURE CITED}

Cade, T.J., and R. W. Fyfe. 1970. The North American peregrine survey, 1970. Canadian Field-Naturalist. 84:231-245.

COSEWIC. 2000. Canadian species at risk, November 2000. Committee on the status of endangered wildlife in Canada. $24 \mathrm{pp}$.

Court, G.S. 1993a. A review of historical nesting records for the peregrine falcon (Falco peregrinus anatum) in Alberta south of $56^{\circ} \mathrm{N}$ : priorities for a recovering population. Unpubl. rept., Alberta Fish and Wildlife Division, Edmonton, AB.

Court, G.S. 1993b. A toxicological assessment of the American peregrine falcon (Falco peregrinus anatum) breeding in Alberta, Canada, 1968 to 1992. Unpubl.rept., Alberta Fish and Wildlife, Edmonton, AB.

Court, G.S. 1994. Population dynamics of American peregrine falcon (Falco peregrinus anatum) breeding in northeastern Alberta, Canada- 1971 to 1993: an evaluation of the need for continued management. Alberta Environmental Protection, Fish and Wildlife Services, Occasional Report Series No. 14. Edmonton, AB. 25 pp.

Endangered Species Conservation Committee. 2000. First report of the Alberta Endangered Species Conservation Committee. Alberta Environment, Fisheries and Wildlife Management Division. 24 pp.

Erickson, G.L. 2000. 2000 prairie region peregrine falcon survey. Alberta Environment, Natural Resources Service, Fisheries and Wildlife Management Division, Lethbridge, Alberta. 23 pp.

Erickson, G.L., R. Fyfe, R. Bromley, G. Holroyd, D. Mossop, B. Munro, R. Nero, C. Shank, and T. Weins. 1988. Anatum peregrine falcon recovery plan. Canadian Wildlife Service, Ottawa, ON. 52 pp.

Fyfe, R. W, S.A. Temple, and T.J. Cade. 1976. The 1975 North American peregrine falcon survey. Canadian Field-Naturalist 90:228-273.

Holroyd, G.L., and U. Banasch. 1990. The reintroduction of the peregrine falcon (Falco peregrinus anatum), into southern Canada. Canadian Field-Naturalist 104:203208.

Johnstone, R.M. 1999. Update of status report on the American peregrine falcon (Falco peregrinus anatum) in Canada. Submitted to the Committee on the Status of Endangered Wildlife in Canada, Ottawa, ON. 44 pp. 
Millsap, B.A., P.L. Kennedy, M.A. Byrd, G. Court, J.H. Enderson, and R.N. Rosenfield. 1998. Review of the proposal to de-list the American peregrine falcon. Wildlife Society Bulletin 26(3):522-538.

Moore, D. 1995a. Northern Alberta wild peregrine falcon summary tables, 1971-1991.

Vol. 1. Unpubl. rept., Alberta Natural Resources, Vermilion, AB.

Moore, D. 1995b. Northern Alberta wild peregrine falcon summary tables, 1992-1996. Vol. 2. Unpubl. rept., Alberta Natural Resources, Vermilion, AB.

Murphy, J. E. 1990. The 1985-86 Canadian peregrine falcon, Falco peregrinus, survey. Canadian Field-Naturalist 104:182-192.

Peakall, D.B., D.G. Noble, J.E. Elliot, J.D. Somers, and G. Erickson. 1990. Environmental contaminants in Canadian peregrine falcons, Falco peregrinus: a toxicological assessment. Canadian Field-Naturalist 104:244-254.

Stepnisky, D.P. 1996. The southern Alberta peregrine falcon reintroduction project (1992-1996): summary and evaluation. Alberta Environmental Protection, Wildlife Management Division, Edmonton, AB. 40 pp.

Stepnisky, D.P. 1998. Demographic features of the recovering peregrine falcon population (Falco peregrinus anatum) in southern Alberta: 1980-1997. Occasional Report Series Number 15. Alberta Environmental Protection, Natural Resources Service, Edmonton, AB. 27 pp. 
Appendix A. Locations of Nesting and Territorial Peregrine Falcons in Alberta 
Figure A1. Locations of peregrine falcon nest sites and occupied territories in southern Alberta.
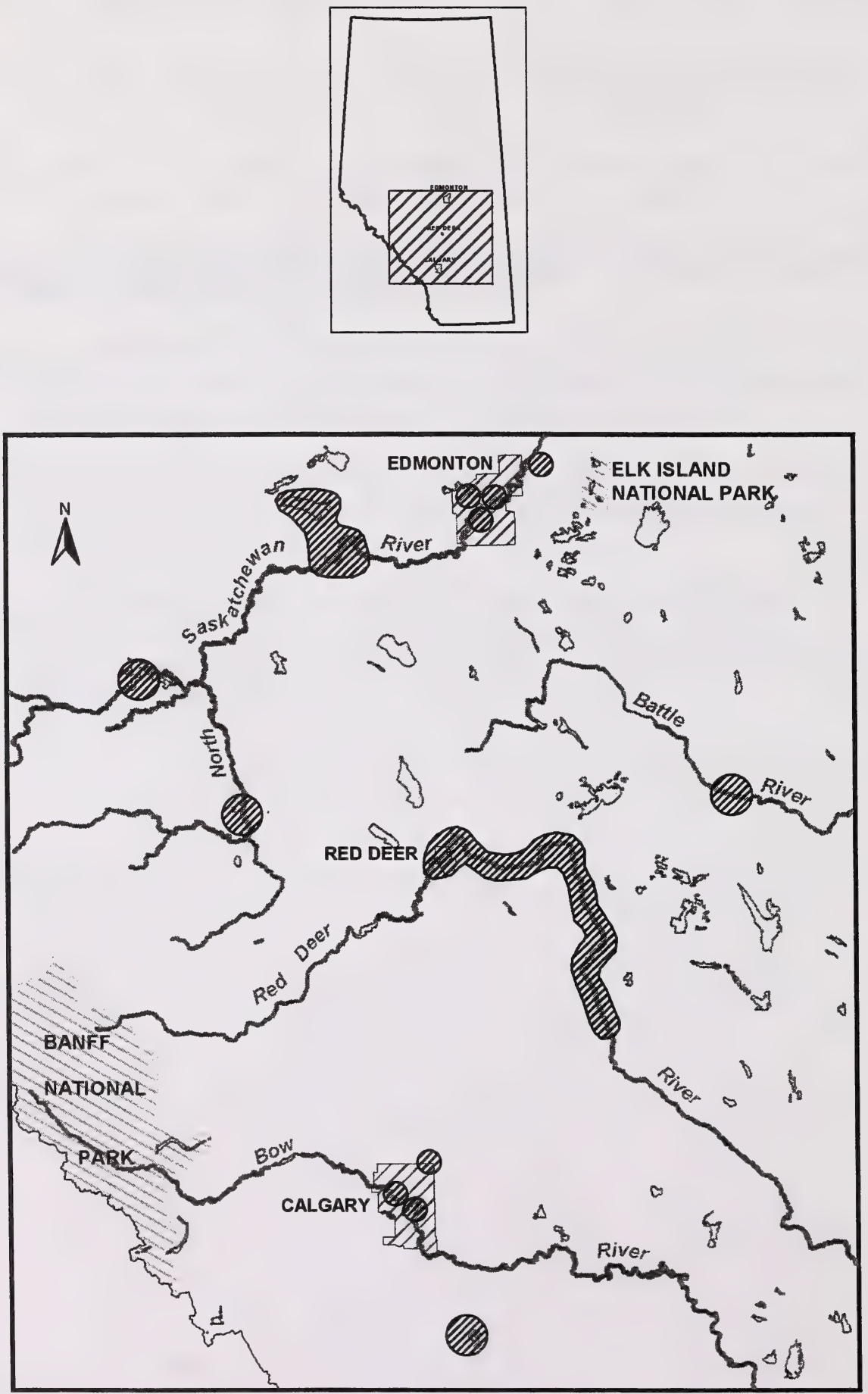
Figure A2. Locations of nest sites and occupied territories in northeast Alberta, 2000.
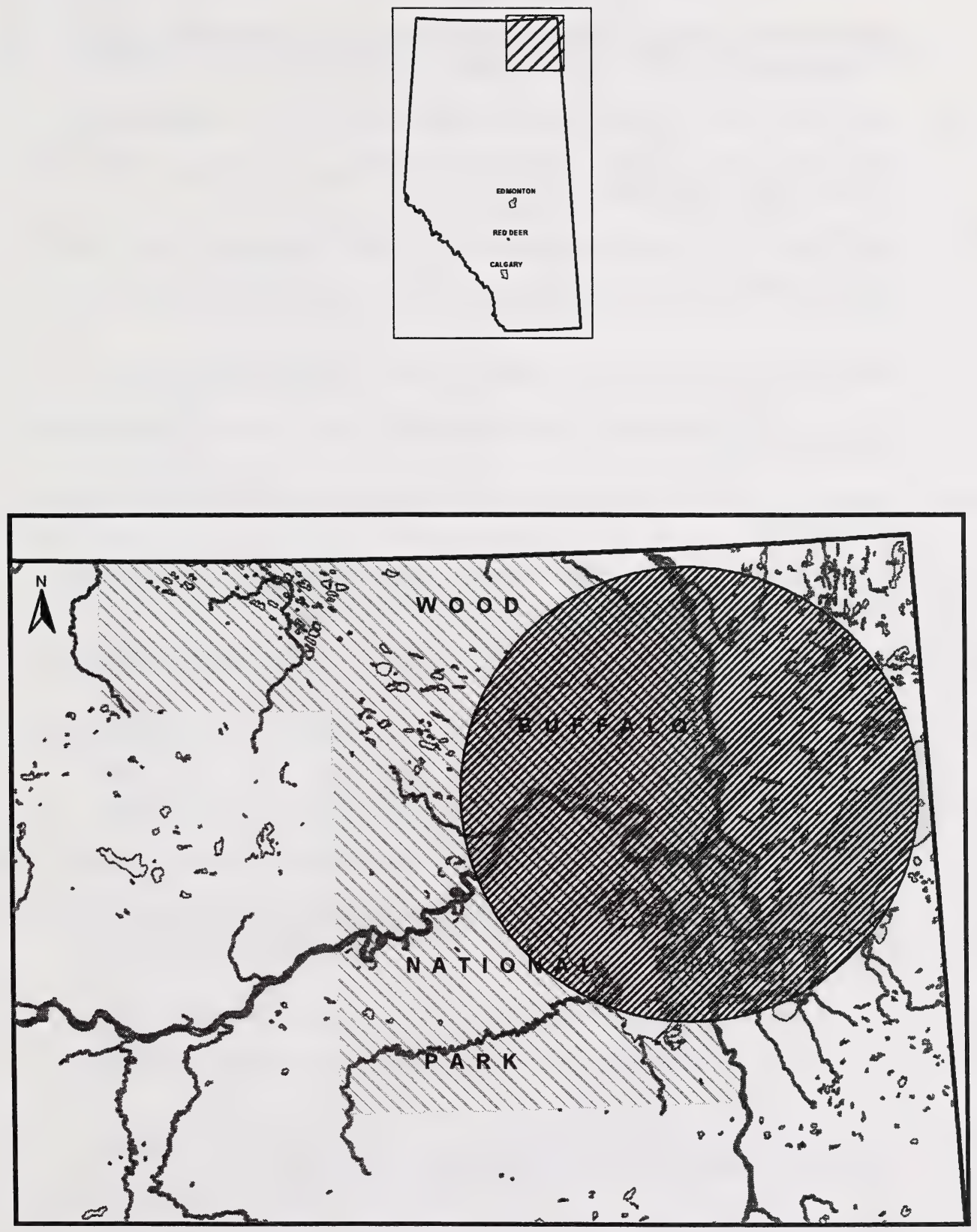


\section{List of Titles in This Series \\ (as of July 2001)}

No. 1 Alberta species at risk program and projects 2000-2001, by Alberta Sustainable Resource Development, Fish and Wildlife Division. (2001)

No. 2 Survey of the peregrine falcon (Falco peregrinus anatum) in Alberta, by R. Corrigan. (2001)

No. 3 Distribution and relative abundance of the shortjaw cisco (Coregonus zenithicus) in Alberta, by M. Steinhilber and L. Rhude. (2001)

No. 4 Survey of the bats of central and northwestern Alberta, by M.J. Vonhof and D. Hobson. (2001)

No. 52000 survey of the Trumpeter Swan (Cygnus buccinator) in Alberta, by M.L. James and A. James. (2001)

No. 6 2000/2001 Brassy Minnow inventory at Musreau Lake and outlet, by T. Ripley. (2001)

No. 7 Colonial nesting waterbird survey in the Northwest Boreal Region - 2000, by M. Hanneman and M. Heckbert. (2001)

No. 8 Burrowing owl trend block survey and monitoring - Brooks and Hanna areas, by D. Scobie and R. Russell. (2000)

No. 9 Survey of the Lake Sturgeon (Acipenser fulvescens) fishery on the South Saskatchewan River, Alberta (June-September, 2000), by L.A. Winkel. (2000)

No. 10 An evaluation of grizzly bear-human conflict in the Northwest Boreal Region of Alberta (19912000) and potential mitigation, by T. Augustyn. (2001)

No. 11 Harlequin duck monitoring in the Northern East Slopes of Alberta: 1998-2000 preliminary results, by J. Kneteman and A. Hubbs. (2000)

No. 12 Distribution of selected small mammals in Alberta, by L. Engley and M. Norton. (2001)

No. 13 Northern leopard frog reintroduction. Raven River - Year 2 (2000), by K. Kendell. (2001)

No. 14 Cumulative effects of watershed disturbances on fish communities in the Kakwa and Simonette watersheds. The Northern Watershed Project. Study 3 Progress report, by T. Thera and A. Wildeman. (2001)

No. 15 Harlequin duck research in Kananaskis Country in 2000, by C.M. Smith. (2001)

No. 16 Proposed monitoring plan for harlequin ducks in the Bow Region of Alberta, by C.M. Smith. (2001)

No. 17 Distribution and relative abundance of small mammals of the western plains of Alberta as determined from great horned owl pellets, by D. Schowalter. (2001)

No. 18 Western blue flag (Iris missouriensis) in Alberta: a census of naturally occurring populations for 2000, by R. Ernst. (2000)

No. 19 Assessing chick survival of sage grouse in Canada, by C.L. Aldridge. (2000)

No. 20 Harlequin duck surveys of the Oldman River Basin in 2000, by D. Paton. (2000) 
No. 21 Proposed protocols for inventories of rare plants of the Grassland Natural Region, by C. Wallis. (2001)

No. 22 Utilization of airphoto interpretation to locate prairie rattlesnake (Crotalus viridis viridis) hibernacula in the South Saskatchewan River valley, by J. Nicholson and S. Rose. (2001) 

National Library of Canada

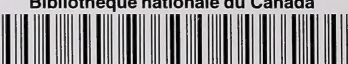

33286523344584 